\title{
Submerged Below the Codex Line: New Zealand's Neglected Nineteenth Century Serial Novels
}

\section{J.E. TRAUE}

The compilation of a checklist of nineteenth-century New Zealand novels and novellas published as serials and never issued as monographs, which provides the core evidence on which this paper is based, was inspired by Lydia Wevers' article in Pacific Highways in 2013. ${ }^{1}$ She was questioning why New Zealand doesn't measure up to Australia's output of great nineteenth-century novels, and providing some very cogent answers based on the evidence currently available. However, I suspected, based on some research dating back to the 1980s and 1990s, that another possible reason might be that New Zealand literary historians had based their analysis on only the novels available in monographic form, and that there may be a goodly taniwha or two, even a great one, lurking elsewhere as serials in the deeper waters of the newspapers and periodicals. What I found down there in the newspapers was far more than I had expected.

New Zealand literary historians have been clearly aware of, but not overly concerned about, the novels serialized in the newspapers. Dennis McEldowney, in the first edition of the Oxford History of New Zealand Literature, noted that local newspapers "had periods when they were hospitable to local writers. They have hardly been explored as yet. W. H. New suggests that here, in the sketches of local life rather than in the more formal fiction and poetry, is the reservoir from which later writing grew." Lawrence Jones, writing on the pioneer period of the New Zealand novel, in the second edition added an extra sentence: "Undoubtedly some [pioneer stories] were serialized in newspapers but not published as books, and these have never been listed and may still lie unnoticed in back files of newspapers or may have disappeared completely in cases where these files are no longer extant." 3 Until now only one attempt has been made to list some of these serials, by Paul Hunt who in 2003 published a list of all the serial fiction in the Otago Witness from 1851 to $1906{ }^{4}$

In what Terry Sturm identifies as "the first full-length published article on New Zealand fiction," Clara Eyre Cheeseman critically surveyed some aspects of nineteenth century New Zealand novels in $1903 .^{5}$ A number of her observations are repeated elsewhere in the Oxford History: namely "that the 'field' of possibilities for the novel in New Zealand was 'as rich and varied as the scenery,' but that it was as yet 'practically untouched",; "that no New Zealand novelist had dealt with 'the forty-acre settlers' who had been worsted in the struggle"; "too much local colour, too great a distinctiveness ... represented the colonial in damaging ways, more particularly so if the writer was a woman"; "Clara Cheeseman's anxiety that some readers might ignore the moral of Louisa Baker's novels and be attracted by the 'regrettable' actions of heroines who walk away from unsatisfactory marriages" (Terry Sturm on Popular Fiction). ${ }^{8}$ Her observations are also featured in The Oxford Companion to New Zealand Literature. $^{9}$

What nobody has commented on was her firm advice to anyone tackling the history of nineteenth-century New Zealand fiction. "It is to the old newspapers that we must go if we want to see the beginning of colonial fiction.... [T] here are in the dusty files of these and other journals many stories of colonial life which have never struggled out of the papers into book form." ${ }^{10}$ As a published novelist and short story writer she knew what she was talking about. Her first short story, "Two Christmas Eves," was published in a newspaper, the Dunedin Saturday Advertiser on 22 December 1877, when she was 25, followed by "Married for his Money" in the Australian Ladies Annual in 1878, "In the Olden Time" serialized in the Saturday Advertiser between 3 and 24 January in 1880, "Estranged for Life" in the Sydney

Journal of New Zealand Studies NS20 (2015), 2-9 
Mail 17 January to 1 May 1880, and "Under Suspicion" in Public Opinion and Saturday Advertiser 1 July to 5 August 1882. Her first and only novel in book form, A Rolling Stone, was published in London by Richard Bentley in three volumes (over 900 pages) in 1886 when she was 34. This novel, the short story "Married for His Money," and her 1903 essay, according to the standard sources, are her only contributions to New Zealand literature. Nelson Wattie and Pauline Neale end their essay in The Oxford Companion thus: "Like so many of her contemporaries, notably Satchell, she fell silent after her industrious beginnings. Perhaps the pressures of being 'literary' in the colony was too hard to bear." 11 This was a reasonable judgment based on the evidence then available. In the dusty files to which, according to Cheeseman, the literary historian "must go" I have located so far three more later novellas: "Had He Known. A Story of the New Zealand Gold Thirst," serialized in four issues of Cassell's Family Magazine (London) in 1892; "On a Lee Shore," serialized in three issues of the same magazine in 1894; and "Sent Into Exile," in the New Zealand Graphic 26 November 1898 to 14 January 1899. According to the New Zealand Herald, she won $£ 30$ as second prize in December 1890 for a story submitted to Cassell's Family Magazine. ${ }^{12}$ I suspect that there are more similar serializations to be discovered.

To be fair to the authors of the Oxford History and the Companion they did not have access to Papers Past. A half hour search there, plus a few hours scanning the pages of the bound volumes of Cassell's Family Magazine in the Auckland Public Library and Dunedin's Saturday Advertiser in the Turnbull, produced these six pieces by Cheeseman and two other novels, one Vincent Pyke's long lost "Eustace Egremont" and a hitherto unknown one by Thomas Bracken, both published in the Saturday Advertiser.

In 1984 in my guide to bibliographical resources for New Zealand studies I noted New Zealand's low "bibliodensity" compared to some other countries, that is, the relatively small number of published monographs and consequently the greater importance of primary materials for scholarly research. ${ }^{13}$ "Monographic resources for New Zealand studies make but a small 'public appearance'; the bulk of the scholarly resources are still submerged below the codex line in manuscripts, archives, paintings, photographs and other primary materials." I contrasted this with the contribution of the newspapers. "If New Zealand's cultural topsoil was deficient in monographs it was enriched by the newspaper printing press from the very beginnings of settlement. ... Such newspapers, because they were present in every large town - and a population of 1,000 was a large town - attracted to themselves a disproportionate share of community information. In the early period the periodical press was weak and locally produced monographs few and far between. In more established societies a different balance was struck between books, periodicals and newspapers. In the old world books had a strong hold before the appearance of periodicals and newspapers; in New Zealand the newspaper established itself first.... The result is that for the early period the newspaper is regarded by researchers as primary source material for New Zealand studies." I concluded thus for an audience at the British Library composed mostly of British academics with an interest in Commonwealth studies: "The opportunity has been taken to issue a caution to those who come to New Zealand studies from research cultures which are substantially book based. We need several generations yet of compilers, editors and assorted pedants to toil among the primary materials to bring a great deal more above the codex line before New Zealand studies can become substantially book-based."14

In 1997 I advanced an argument about the significant role of newspapers in literary publishing. ${ }^{15}$ In Britain, where at the beginning of the nineteenth century the weekly and monthly periodicals dominated the publication of serial fiction, the shift to serial fiction in the newspapers in the 1850s was a response to two developments. First, the growth of a lucrative mass market for cheap recreational reading; and second, the removal of the last of the taxes on knowledge in 1855 , the $1 \mathrm{~d}$ per copy stamp on newspapers carrying news, that is, information 
concerning recent public occurrences. Once this tax was lifted many of the features of the cheap weekly periodicals that had grown to meet the public demand for recreational reading (especially for serial fiction), and which had evaded the knowledge taxes by avoiding printing any news, migrated to the newspapers as a means of boosting their circulation. Provincial newspapers became significant outlets for fiction; a serial novel appeared in the North Briton (Edinburgh) in 1855 and was quickly followed by other provincial newspapers. WilliamWestall claimed in 1890 that "there is hardly a small town in the kingdom without at least one local sheet, whose chief attraction is a serial romance." 16 The Times of London made few concessions to the new mass market and reluctantly published its only piece of serialized fiction in 1905.

In New Zealand and Australia the settlers' appetite for recreational fiction matched, and possibly even exceeded, that in their homelands. One response was the creation of large numbers of library societies, small subscription lending libraries owned by their members, scattered across the countryside and, in a development unmatched elsewhere, their subsidization by state, provincial and, in New Zealand, by central government from the 1850s. ${ }^{17}$ Between 1840 and 1914, 769 such libraries had been founded in New Zealand. By 1908, when the number of active subscription lending libraries reached its peak at 437, there was hardly a population centre in New Zealand that lacked a library. In 1906, Otamatea County had six libraries for 2,921 people; Weber County one library for 593, Cheviot one library for 1,065. In 1878 there was one library for 1,529 people, in 1898 one for every 2,608, in 1906 one for every 2,099. However, most of these libraries soon degenerated into book clubs supplying popular fiction to a handful of subscribers. In 1916 a survey found that 30\%, 123 of the 408 receiving the government subsidy, were buying nothing but fiction and that except for the 11 major libraries 89 per cent of the purchases by these libraries consisted of fiction.

Our newspapers also responded to this demand and were quick to integrate fiction and other entertainments into their pages. New Zealand did not have a newspaper tax discouraging the mixing of news and entertainment, but it had other problems. First were those arising from the irregular supply of news in the early period before the telegraph. Overseas and local news arrived by ship in other newspapers and bad weather or a wreck could lead to long delays. The expedient adopted was to reprint literary extracts to fill the spaces between the advertisements. Many of these were anonymous and without attribution and were probably lifted from overseas newspapers and periodicals without payment.

In 1866, that vociferous Dunedin critic of colonial standards, J. G. S. Grant, commented that of the seventeen dailies then being published in New Zealand "eleven are purely advertising sheets, plus the insertion of a piece of a novel or tale successively published for the amusement of the gaping settlers who have access to no other sources of literature."18

Second was the near impossible task of distributing a daily newspaper beyond the towns to thinly settled hinterlands. The solution developed in New Zealand and Australia was the separate weekly supplement containing the major news stories of the preceding week, bulked out with a serialized novel, short stories, puzzles and games, or an expanded Saturday issue with a serial novel and short stories, both available on a separate subscription for country readers. For example, the Wanganui Herald, founded in 1867 as a penny newspaper, published a literary supplement, the Weekly Herald later the Yeoman, from 1869-1906. The Auckland Star, which began as the Evening Star in 1870, inaugurated a Saturday supplement in 1875 which survived until the early 1940s.

There was a parallel development in Britain from the late 1860s, but apparently for different reasons, with the appearance of "supplementary weeklies," either a separate or autonomous publication or a weekend or companion edition of a daily paper, both tending to give greater weight to features and entertainment. In declining the offer by Watt's Literary Agency of a novel by Wilkie Collins in 1883, the editor of the Western Daily Mercury wrote 
“... his stories are too high class... [S]ince we have divided the old Saturday paper into two distinct papers, a daily and a weekly, the latter now appeals almost solely to the working class. For those we find a different, \& from an artistic point of view, far inferior tale the more telling, $\&$ as furthermore the inferior tale is much the cheaper, it would be folly to waste this extra money." 19 One can see the beginnings, from the 1880 s, of the class lines being drawn between British newspapers.

One of the first serializations in New Zealand of a named author was that of BulwerLytton's What Will He Do With It, beginning in the January 1858 issue of the Hawkes Bay Herald. Its first publication was in Blackwood"s Magazine, June 1857 to January 1859, later published as a book in 1859 . Thereafter, practically every newspaper in New Zealand published a serialized novel once a week until the early 1940s, when wartime newsprint rationing strangled the supplements. The Auckland Star on Saturday 6 April 1935 consisted of 22 pages plus a supplement of 16 pages containing the first instalment of the novel "Cherry Fare" by Leslie Cargill. By Saturday 4 April 1942 it was down to 10 pages and the supplement and the serial had disappeared never to reappear. These novels often appeared under headings such as "The Novelist," "The Storyteller," "Serial Story" or "Our Serial Story," "Literature" and occasionally under "The Sketcher." In Australia, the Sydney Mail, the weekly edition of the Sydney Morning Herald, began serializing fiction in 1860, followed by most other newspapers. A high proportion of the novels serialized in New Zealand newspapers, and there were hundreds of them, were written by overseas authors, mostly British, with a handful of Americans (E. Werner, Seward W. Hopkins, Sylvanus Cobb, Harriet Lewis, Bertha M. Clay) and Australians (Alexander Montgomery, John Lang, Marcus Clarke, Harold W. H. Stephen) and were about to be or had been published as monographs. Agencies in England and Australia, especially Tillotson's Fiction Bureau of Bolton in Lancashire and Gordon and Gotch in Australia, bought colonial or Australasian rights from the authors or publishers and farmed them out to local newspapers. Other agencies known to have supplied fiction to New Zealand newspapers include Cameron, Laing and Co. and S. and D. Reid of Melbourne, and McClure's Literary Press in the United States. ${ }^{20}$ A well-known author's serial rights for a novel were available for $£ 100$ for Australasian or $£ 75$ for a single colony. Serial rights for lesser writers, and most of the overseas writers appearing in New Zealand newspapers were lesser writers who don't feature in standard literary histories, were available for a little as £10. A comparison between writers serialized in Australian and New Zealand newspapers indicates that the larger Australian newspapers - the Age, and the Leader of Melbourne, the Sydney Mail and Town and Country Journal - could afford more established and popular writers than their New Zealand counterparts. One year the readers of the Australasian were treated to three full-length novels serialized simultaneously. The authors: George Eliot, Anthony Trollope, and Marcus Clarke. No New Zealand newspaper ever came close to matching that trifecta.

The first New Zealand author to have a novel published by a local newspaper was Benjamin Farjeon whose "Life and Adventures of Christopher Congleton" appeared in the Otago Witness in 1862, followed by Charlotte Evans's "Guy Eversley" in the Oamaru Times in 1865. Neither of these novels appeared as monographs. Although New Zealand authors made up a small proportion of the novelists serialized in New Zealand newspapers, New Zealand writers of shorter pieces, sketches, tales, true stories and short stories fared much better and were well represented from the 1860s. Paul Hunt's analysis of the serial fiction in the Otago Witness, which was known to favour local writing, lists 102 novels published between 1862 and 1900, of which 24 were by New Zealand writers.

Australian novelists did slightly better than their New Zealand counterparts. Elizabeth Morrison's survey of 100 Australian newspapers published on or near 31 August 1899 turned up serialization of 28 separate titles of novels (one title could be serialized simultaneously by several newspapers) six of which were by Australian authors. ${ }^{21}$ And an Australian novelist who 
achieved serial publication in a newspaper was more likely to have his novel reprinted as a monograph. Toni Johnson-Woods, in her Index to Serials in Australian Periodicals and Newspapers, Nineteenth Century, analysed the book-length (40,000 words or more) serials in 15 newspapers and periodicals. She estimates that nearly 1,000 serial titles were published in these 15 publications between 1853 and 1899 . Only 174 were colonial, that is written in, set and/or first appeared in colonial publications. Of these 174, only $39(22 \%)$ appeared in book form. More Australian authors appeared in the earlier years but after 1870 imported fiction supplied by the British and American fiction bureaux usurped the local material. By the 1890s many of the weeklies had stopped publishing local writing.

Australian academics have long been aware of the rich field provided by the large volume of fiction serialized in their newspapers and a number of small indexing projects to identify Australian content have been launched in the past forty years, many available only on cards or microfiche or out of print, but the formidable size of the task has cooled enthusiasm until recently. The Colonial Newspapers and Magazines Project based at the University of New South Wales in Canberra has made some impressive progress. An ambitious project to use automatic methods to search Trove's digitized newspaper database to create a comprehensive bibliographic index and a textual archive of serialized fiction in Australian newspapers from 1850 to 1914 has just been described in a recent issue of Script and Print ${ }^{22}$ and it would seem that similar techniques could be used to analyze Papers Past for fiction in New Zealand newspapers.

My far from comprehensive checklist identifies the first publication of 97 New Zealand novels and novellas in New Zealand newspapers and one in a periodical, of eight in Australian newspapers and two in periodicals, of two in British newspapers and four in British periodicals from 1861 to 1900 , a total of 114 , none of which has been published as a monograph. James A. S. Burns, in his 1981 bibliography, lists 65 titles for the period 1861-1900, of which only one, Vincent Pyke's "Lost at the Gold-fields" was published, he claims, in a periodical, namely Chamber's [sic] Journal in $1868 .{ }^{23}$ In fact it was not a novel, but a four-page short story, appearing anonymously in the 27 February issue of Chambers's Journal in 1869 and reprinted in the Southern Mercury in June 1875. Of Burns' 64 monographs, only four were issued as three-deckers. Of the 114 in the checklist, 13 were published over 26 weeks or so, the equivalent of a standard three-decker novel.

Lawrence Jones, in the second edition of the Oxford History, mentions by title 92 novels published between 1861 and 1900, five of which were published only as serials, giving a total of 87 novels in monographic form. He casts his net far wider than Burns.

Their criteria for a New Zealand novel differ: only 49 of Burns' titles appear in Jones' essay.

Using the subject heading "New Zealand fiction-nineteenth century" in the National Library's catalogue I have calculated that there were some 82 separate titles of New Zealand novels issued as monographs between 1861 and 1900, of which some ten or more have been identified since Bagnall and Burns. The full total under this subject heading is 131, but this includes collections of short stories, reprints, and titles issued after 1900 or mistakenly included.

It would be safe to conclude that there are slightly fewer than one hundred New Zealand novels published as monographs between 1861 and 1900, contrasted with the 114 published only as serials that are identified in the checklist.

The evidence gathered in the checklist fully supports Clara Cheeseman's verdict in 1903, that "many stories of colonial life ... have never struggled out of the papers into book form." 24 The very opposite was true in Britain according to Graham Law: "it seems likely that, for almost the whole of the Victorian period, a significant majority of 'original' novels published as books had appeared previously in monthly or weekly instalments, as independent numbers, in magazines, or in the pages of the newspapers." ${ }^{25}$ He notes that in the early Victorian period 
there was "undoubtedly a vast and still largely uncharted sea of stories, published serially in cheap popular periodicals but never reprinted as books," but these were designed for the "slum market" of the Salisbury Square publishers and the penny bloods. The high rate of translation from newspaper serial to monograph in Britain in the late nineteenth century may well have led New Zealand literary historians to assume that New Zealand was no different, that most novels of significance had appeared as monographs and that there was little of value for them in our newspapers.

Will this new evidence, that there were as many novels published only in serial format as there were in monograph format, have a major influence on the standard interpretations of New Zealand nineteenth-century fiction? I am but a humble bibliographer, mapping out the literary terrain, identifying, describing, and organizing the evidence. I leave it to the historians and critics familiar with the existing monographic evidence to make the literary evaluations on the importance of these serial novels in the bigger picture.

Have I found any great nineteenth century New Zealand novels? I doubt it, but I leave that judgment to the experts. I had high hopes for Vincent Pyke's long lost novel set mostly in the North Island during the land wars, Eustace Egremont, serialized in Thomas Bracken's Saturday Advertiser, 1 May - 31 July 1880, but at a first glance it looks like a pot-boiler for the British market. There are passing contemporary references to this novel, and Clara Cheeseman mentions it in "Colonials in Fiction," but as of 1998 the Oxford Companion notes it as "cannot now be traced" (456).

A number of hitherto unrecognized novelists will need to be admitted to the literary pantheon. E. M. and J. Bourke for one novel, Supplejack, published in the Melbourne Leader in 1883; Thomas Bracken re-evaluated for one novel, Golden Foundations, published in the Saturday Advertiser in 1879; Frances Cotton, writing under the pseudonym Fabian Bell for an extraordinary output of some 10 novels between 1877 and 1897, and short stories, sketches and travel pieces over a period of 42 years, 1877-1919, mostly in the Otago Witness but in other South Island newspapers and the New Zealand Illustrated Magazine and Zealandia; R. C. Ferguson for one novel in the Saturday Advertiser; Arthur Fookes for two novels in the New Zealand Mail 1887 and the Auckland Star 1888; J. W. McDougall for one novel in the Hawkes Bay Herald 1892-3; Ernest Mansfield for one novel in the Yeoman; John Miller writing under the pseudonym Sagitta for two Southland novels in the Otago Witness and the Invercargill Weekly Times; Lizzie Frost Rattray for three novels in the Waikato Times and one in Cassell's Family Magazine; J. J. Utting for two novels in the Saturday Advertiser; Scott Webster for one novel in the Weekly Press.

As well, established writers such as Louisa Baker, normally writing under the pseudonym Alien but producing two early novels under the pseudonym Alice; Clara Cheeseman, with three later novels; W. S. Walker, writing under the pseudonym Coo-ee, for two, possibly three more novels in the Observer and Free Lance; and Frank Westbury, for three more novels published in the Tuapeka Times and two Australian newspapers, will need to be re-evaluated.

The research uncovered an intriguing byway, the serialization of New Zealand novelists in British provincial newspapers. My estimate is that well over a thousand serial novels by British writers were imported into New Zealand newspapers from the 1860s to the 1940s. We exported at least three novels by two New Zealand writers to the British provincial newspapers in the nineteenth century. Fabian Bell's [Frances Cotton's] "A Letter in Cypher" first published in the Otago Witness in 1882-3 was reprinted in the Manchester Evening Mail in 1895, the Exeter and Plymouth Gazette in 1897, the Blackburn Standard in 1898 and the Lincolnshire Echo in 1900, and her "Price of a Life" was first published in five British provincial newspapers in 1895-6 before being published in the Otago Witness in 1896, and then reprinted in two other British provincial newspapers in 1897 and published in two Australian newspapers. Arthur 
Fookes' first novel, "In the Flesh and the Spirit" was first published in five or more British provincial newspapers in 1886 before appearing in the New Zealand Mail in 1887.

I began this exercise with the belief that I would probably uncover no more than a handful of nineteenth-century serialized novels and was surprised at how many existed. But it was even more surprising to discover just how much prose fiction appeared in the newspapers, especially in the Saturday editions or the supplements, to discover that practically every newspaper in the country was regularly publishing serialized novels, nearly all of which were written by overseas writers, for a period of some 80 years, from the 1860 s to the early1940s, and to realize what this might mean for the study of literary and print culture, especially reading habits and the formation of reading tastes.

My assumption had been that the main source of recreational prose fiction for New Zealand readers was the social libraries, that is the hundreds of subscription libraries owned by their subscribers, receiving government subsidies and defined by law as "public libraries," augmented by a small number of commercial lending libraries in the larger towns and cities. In my earlier research I established that between 1873 and 1896, paid up members of these "public" libraries represented between 2.3 and $3.1 \%$ of the total population, or between 3.85 and $5.36 \%$ of the population over age 15. Assuming that one subscriber shared books with two other family members, between 7 and $10 \%$ of the total population were reading material from these libraries, or between 11 and $16 \%$ of the population over age 15 . This is a very conservative estimate because the census of libraries grossly underrepresented public libraries and the average colonial family was much larger than three people. Another source of fiction was by purchase, but very few had the wherewithal to purchase the representative range of contemporary fiction widely available in local bookshops.

There were almost as many newspapers as libraries and in the golden era from the $1860 \mathrm{~s}$ most towns had a local newspaper. Scholefield claimed that between 1860 and 1879, 181 newspapers were founded, and Harvey's survey of 1983 identified some 800 newspaper titles published before 1940. There are no reliable figures for the national readership of New Zealand newspapers in the nineteenth century but Ross Harvey has estimated that the "percentage of the total population ... who potentially saw a newspaper falls in the range $7-12 \%$," and adds "My guess is that the real range is lower, perhaps of the order of 5\%." 26 These readers were exposed for some 80 years to the serial novels appearing every week.

From the surviving printed catalogues and the very occasional survival of the stock of a nineteenth-century social library we have a reasonable idea of the range of books available to their subscribers even if the records are scanty for identifying what they read. But could it be that the newspapers were the major source of fiction for most New Zealanders in the nineteenth century? Was J. G. S. Grant right, that the "piece of a novel or tale successively published" in the newspapers provided the amusement for "the gaping settlers who have access to no other sources of literature"?

\footnotetext{
${ }^{1}$ Lydia Wevers, "First, Build Your Hut," Pacific Highways. Griffith Review 43 (2013): 261-67

${ }^{2}$ Dennis McEldowney, "Publishing, Patronage, Literary Magazines," in The Oxford History of New Zealand Literature, ed. Terry Sturm, 2nd ed. (Auckland: Oxford Univerity Press, 1991), 60.

${ }^{3}$ Lawrence Jones, "The Novel," in The Oxford History of New Zealand Literature in English, ed. Terry Sturm, 2nd ed. (Auckland: Oxford University Press, 1998), 121.

${ }^{4}$ Paul Hunt, "Serial Fiction in the Otago Witness 1851-1906," BSANZ Bulletin 27, no. 3 \& 4 (2003): 94-103.
} 
${ }^{5}$ Terry Sturm, "Popular Fiction," in The Oxford History of New Zealand Literature, ed. Terry Sturm, 2nd ed. (Auckland: Oxford Universiry Press, 1998), 581; Clara Eyre Cheeseman, "Colonials in Fiction," New Zealand Illustrated Magazine 7, no. 4 (1 January 1903): 273-82.

${ }^{6}$ Lawrence Jones, "The Novel," 134.

${ }^{7}$ Lydia Wevers, "The Short Story," in The Oxford History of New Zealand Literature in English, ed. Terry Sturm, 2nd ed. (Auckland: Oxford University Press, 1998), 249.

${ }^{8}$ Terry Sturm, "Popular Fiction," in The Oxford History of New Zealand Literature in English, ed. Terry Sturm, 2nd ed. (Auckland: Oxford University Press, 1998), 618.

${ }^{9}$ Roger Robinson and Nelson Wattie, ed., The Oxford Companion to New Zealand Literature (Melbourne: Oxford University Press, 1998), 102.

${ }^{10}$ Cheeseman, "Colonials," 274.

${ }^{11}$ In The Oxford Companion to New Zealand Literature, 102.

1231 Jan 1891, 4. Unidentified, possibly "Had He Known."

${ }^{13}$ Paper delivered to the British Library Colloquium on Australian and New Zealand Studies, published in New Zealand as New Zealand Studies: A Guide to Bibliographic Resources (Wellington: Victoria University Press for the Stout Centre, 1985), 8.

${ }^{14}$ J. E. Traue, New Zealand Studies, 9; 12-13; 27.

${ }^{15}$ J. E. Traue, "But Why Mulgan, Marris and Schroder: the Mutation of Local Newspapers in New Zealand's Colonial Print Culture," BSANZ Bulletin 21, no. 3 (1997):107-15.

${ }^{16}$ Quoted in Graham Law, Serializing Fiction in the Victorian Press (Basingstoke: Palgrave, 2000), 181.

${ }^{17}$ See J. E. Traue, "The Public Library Explosion in Colonial New Zealand," Libraries and the Cultural Record 42, no. 2 (2007): 151-64.

${ }^{18}$ J. G. S. Grant, "The Newspaper Literature of New Zealand," Delphic Oracle I (1866): 7.

${ }^{19}$ Law, Serializing Fiction, 142.

${ }^{20}$ Ross Harvey, "Sources of 'Literary' Copy for New Zealand Newspapers," BSANZ Bulletin 27, no. 3 \& 4 (2003): 83-93; Charles Johanningsmeier, Fiction and the American Literary Marketplace (Cambridge: Cambridge University Press, 1997), 76.

${ }^{21}$ Elizabeth Morrison, "Retrieving Colonial Literary Culture," BSANZ Bulletin 13 (1989): 27-36.

${ }^{22}$ Katherine Bode and Carol Hetherington, "Retrieving a World of Fiction: Building an Index - and an Archive - of Serialized Novels in Australian Newspapers, 1850-1914," Script and Print 38, no. 4 (December 2014): 197-211.

${ }^{23}$ James A. S. Burns, New Zealand Novels and Novelists 1861-1979: An Annotated Bibliography (Auckland: Heinemann, 1981).

${ }^{24}$ Cheeseman, "Colonials," 274.

${ }^{25}$ Law, Serializing Fiction, 13.

${ }^{26}$ Ross Harvey, "The Power of the Press in Colonial New Zealand," BSANZ Bulletin 20, no. 2 (1996): 138. See also Harvey's "Economic Aspects of Nineteenth-Century New Zealand Newspapers,"

BSANZ Bulletin 17, no. 2 (1993): 55-78; "Formula for Success: Economic Aspects of the NineteenthCentury New Zealand Press," in An Index to Civilization (Melbourne: Centre for Bibliographic and Textual Studies Monash University, 1993), 207-22; "Circulation Figures of Some Nineteenth Century New Zealand Newspapers," Archifacts 1988 no. 4 (1988): 20-29. Harvey's 5\% figure is disputed. The very low circulation of newspapers before steam driven presses were installed, when 100-150 copies made a newspaper financially viable, skews the figures. 